\title{
Body temperature reduction in young C3H mice following removal from the nest*
}

\author{
Z. MICHAEL NAGY \\ Bowling Green State University, Bowling Green, Ohio 43403 \\ and \\ JAMES A. ANDERSON \\ C. W. Post College, Greenvale, N.Y. 11548
}

To determine the ability of young $\mathrm{C} 3 \mathrm{H}$ mice to maintain nest-level body temperatures upon removal from the nest as a function of age, separate groups of mice were tested at $1,5,8,10,12,15$, or 20 days of age. The mice were placed in small chambers maintained at $24^{\circ} \mathrm{C}$, and colonic temperatures were recorded immediately upon removal from the nest and 3 and $15 \mathrm{~min}$ following exposure to $24^{\circ} \mathrm{C}$. The results demonstrated that mice less than 12 days of age exhibit losses in body temperature, with younger animals showing the greater losses, while mice older than 12 days increased their temperatures over the 15 -min interval.

It is well documented that young rats (e.g., Fairfield, 1948; Adolph, 1957) and mice (e.g., Pincus, Sterne, \& Enzmann, 1933) are essentially poikilothermic at birth, with underdeveloped capacities for either producing heat or minimizing its loss (Adolph, 1957). Without the protection of the mother, littermates, and nest, the newborn animal's temperature tends to fluctuate directly with the ambient temperature. By 7 days of age, heat production mechanisms appear to begin development (Hsieh \& Carlson, 1957; Lagerspetz, 1962). With further maturation, mice appear to reach adult levels of resistance to cold by 28 days of age (Lagerspetz, 1962), although their ability to adapt to repeated cold exposures increases through at least 36 days of age (Nagy, 1966).

Although a number of studies have reported actual temperature recordings of the neonate during a period away from the nest, these studies have typically presented data for only one age (Hutchings, 1963) or, when more than one age was used, for repeated exposures of the same animals to either different temperatures (Lagerspetz, 1962) or on successive days (Haggett \& Werboff, 1969). There is evidence that rats exposed to lowered temperatures during the first week of life show an earlier maturation of the adrenal ascorbic acid response to cold than do control animals without previous exposure to cold (Levine, Alpert, \& Lewis, 1958; Levine \& Lewis, 1959; Schaeffer, 1963). It is possible, therefore, that repeated use of the same animals may have accelerated the maturation of the thermoregulatory system in these earlier studies.

\footnotetext{
* This research was conducted while the authors were at Susquehanna University and w a s s p ported by N I M H Grant MH-14108-01.
}

The purpose of the present study was to provide some basic data on the development of the ability to maintain nest-level body temperatures in young $\mathrm{C} 3 \mathrm{H}$ mice which have been removed from the nest and isolated at $24^{\circ} \mathrm{C}$, without the confounding factors of either exposure to several temperatures on the same day or to more than a single exposure.

$$
\text { SUBJECTS }
$$

The Ss were $140 \mathrm{C} 3 \mathrm{H}$ mice divided into seven age groups of $1,5,8,10$, 12,15 , and 20 days of age, according to a modified split-litter design. Each age group comprised 10 males and 10 females. The mice were born and reared until testing in $12 \times 8 \times 5$ in. polyethylene cages with wire-grid tops, wood-chip shavings on the floor, and ad lib access to food and water. The Ss were maintained in the laboratory colony at $23^{\circ} \pm 1^{\circ} \mathrm{C}$ and on a 12 -h light-dark cycle.

\section{APPARATUS}

The apparatus used for measuring colonic temperatures was an Ellab Universal Thermocouple thermometer (Type TE3; differential sensitivity $\pm 0.1^{\circ} \mathrm{C}$ ). A Type RM6 thermometer probe (1.2 mm diam) was used in measuring colonic temperatures of mice 15 and 20 days of age, while an ISC probe ( $0.3 \mathrm{~mm}$ diam) with a silicone rubber tip was used for mice 12 days of age and younger. An Akro-Mils cabinet (XT-315) was used to house $\mathrm{Ss}$ during testing. Each drawer was divided in half, providing $5 \times 3 \frac{1}{2} \times 3$ in., and the floor was covered with a paper towel. The air temperature in each drawer when closed with no $\mathrm{S}$ present was $24^{\circ} \pm .1^{\circ} \mathrm{C}$.

\section{PROCEDURE}

At the appropriate age, each $\mathrm{S}$ was removed from the rearing cage by the tail, and its colonic temperature was measured as quickly as possible. This temperature was defined as the nest-level temperature, or $0 \mathrm{~min}$. The $\mathrm{S}$ was then placed into one of the empty drawers of the cabinet. Three minutes after the first temperature measurement, $S$ was removed from the drawer by the tail and its colonic temperature was again recorded. The $S$ was returned to the drawer until $15 \mathrm{~min}$ had elapsed since removal from the nest, and its colonic temperature was then recorded for the last time. Following the third measurement, S was weighed and then discarded.

\section{RESULTS AND DISCUSSION}

Figure 1 shows the mean colonic temperatures of each age group immediately upon removal from the nest and 3 and $15 \mathrm{~min}$ after removal. These data were analyzed by means of a three-way analysis of variance with one repeated measure. The results of the analysis indicated that there was a reliable increase in colonic temperatures as Ss became older $(F=193.99 ; \quad \mathrm{df}=6,126 ; \mathrm{p}<.0005)$, no main effect due to $\operatorname{sex}(F<0.1$; $\mathrm{df}=1,126$ ), a reliable difference in colonic temperatures at the different time intervals away from the nest $(\mathrm{F}=924.82 ; \mathrm{df}=2,252 ; \mathrm{p}<.0005)$, and an Age by Time of Measurement interaction $(F=289.69 ; \mathrm{df}=12,252$; $\mathrm{p}<.0005$ ). It should be pointed out that at every age tested, the colonic temperatures at each time interval showed very little variation between Ss, with the maximum difference within any time interval at any age being $3.7^{\circ} \mathrm{C}$, leading to highly significant statistical differences between means which differed by only a few degrees. For example, individual comparisons of colonic temperatures within each age group showed reliable differences between every interval (all Fs $>3.90 ; \mathrm{df}=12.252 ; \quad$ p $<.0005)$, except at 12 days of age, where the 0 and 15-min interval temperatures did not differ statistically $(F=0.89$; $\mathrm{df}=12,252$ ).

Although the main effect for differences due to sex was not reliable, there was a reliable Sex by Time of

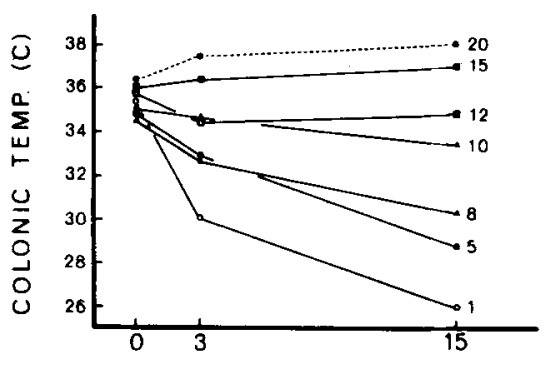

TIME IN MINUTES

Fig. 1. Mean colonic temperatures as a function of age and time away from the nest. 
Table 1

Mean Colonic Temperature Change During 15-Min Exposure to $24^{\circ} \mathrm{C}$ for Males and Females

\begin{tabular}{lccccccc} 
& \multicolumn{8}{c}{ Age (Days) } \\
\cline { 2 - 8 } Sex & 1 & 5 & 8 & 10 & 12 & 15 & 20 \\
\hline Males & -8.59 & -6.10 & -3.94 & -1.69 & -0.29 & +1.30 & +1.85 \\
Females & -9.99 & -6.15 & -4.50 & -2.81 & -0.03 & +0.83 & +1.65 \\
\hline
\end{tabular}

Measurement interaction $(\mathrm{F}=7.79$ $\mathrm{df}=2,252 ; \mathrm{p}<.0005)$. Female mice younger than 12 days of age consistently had higher nest-level temperatures than males but lower temperatures following the $15-\mathrm{min}$ exposure to $24^{\circ} \mathrm{C}$. Females older than 12 days of age also had higher nest-level temperatures than males and, although able to increase their colonic temperatures over the $15-\mathrm{min}$ interval like the males, did not increase as much as did the males, leading to a reliable three-way interaction of Age by Sex by Time of Measurement $(\mathrm{F}=2.22 ; \quad \mathrm{d} f=12,252 ; \quad \mathrm{p}<.01)$. Table 1 presents the mean colonic temperature changes for both males and females at each of the seven ages during the $15-\mathrm{min}$ exposure to $24^{\circ} \mathrm{C}$. It is not clear why this difference between males and females occurred. Body weights did not differ reliably between sexes at any of the ages in this study.

The overall results of the present study are quite clear in demonstrating that in all animals younger than 12 days of age, removal from the nest or home cage produces a significant drop in colonic temperature. At 1 day of age, Ss show a drop of about $4.5^{\circ} \mathrm{C}$ after $3 \mathrm{~min}$ away from the nest and a further $5^{\circ} \mathrm{C}$ drop after an additional $12 \mathrm{~min}$. The colonic temperatures of 1-day-old Ss almost reached the ambient temperature $\left(24^{\circ} \mathrm{C}\right)$ within the 15-min period. As Ss grow older, there is less of a drop in colonic temperature after both 3 and $15 \mathrm{~min}$. This may reflect two processes. First, as the animal matures, it is becoming larger and therefore has more body mass to be cooled. At the same time, the mouse is becoming better insulated and begins to grow fur. Both of these factors would tend to decrease the amount of body heat lost during exposure to lower temperatures. The second obvious possibility is the development of the thermoregulatory mechanisms, including shivering, as the mouse matures.
At 12 days of age, Ss exhibited a significant decrease in temperature after $3 \mathrm{~min}$, but then reliably increased their temperature during the next $12 \mathrm{~min}$. At 15 and 20 days of age, there were significant increases in temperature at both 3 and $15 \mathrm{~min}$ following removal from the nest. The reason for this increase appears due to the enclosed drawers used to house Ss during testing. In their living cages, Ss were able to radiate body heat, and the heat exchange was facilitated by air convection in the air-conditioned test room. However, in the enclosed drawers, there was little air convection, and hence this type of heat exchange was inhibited. Thus, Ss which are thermoregulating and producing body heat in significant amounts would be expected to show an increase in colonic temperatures. Younger Ss, in contrast, would be expected to show decreases in colonic temperatures if they were not producing enough body heat to replace that lost by radiation to the surrounding air. The present results indicate that the mouse begins producing body heat in significant amounts between 10 and 12 days of age, which is in general agreement with studies suggesting that the development of thermoregulatory ability in the rat begins during the second week of life.

A final point of interest in the present study is the change in nest-level temperatures as a function of age. There was a reliable decrease in temperature between 1 and 8 days of age and then a reliable increase between 8 and 10 days of age. The drop in temperature between 1 and 8 days of age appears due to at least two factors. First, with increased maturation, the mice are becoming better coordinated and more mobile, and they attempt to crawl from the nest more than do younger animals. Second, it appears that the mother spends increasing amounts of time away from the mice after the third or fourth day after birth, as has been reported for the rat (Schaeffer, 1963). and this would allow the temperature of the nest to decrease in her absence. The combination of these factors would result in lower temperatures in the nonthermoregulating neonate. The reliable increase between 8 and 10 days of age appears due to the combination of increased body mass, pellage, and the development of thermoregulatory capacity.

\section{REFERENCES}

ADOLPH, E. F. Ontogeny of physiological regulations in the rat. Quarterly Review of Biology, 1957, 32, 89-137.

FAIRFIELD, J. Effects of cold on infant rats: Body temperatures, oxygen consumption, electrocardiograms. American Journal of Physiology, 1948. 155, 355-365.

HAGGETT B. N. \& WERBOFF, J. Temperature reduction in neonatal mice: Effects on later behavior. Developmental Psychobiology, 1968, 1, 257-265.

HSIEH, A. C. L., \& CARLSON, L. D. Role of adrenaline in the chemical regulation of heat production. American Journal of Physiology, 1957, 190, 243-246.

HUTCHINGS, D. E. Early "experience" and its effects on later behavioral processes in rats: III. Effects of infantile handling and body temperature reduction on later emotionality. Transactions of the New York Academy of Sciences, 1963, 25, 890-901.

LAGERSPETZ, K. The postnatal development of homoiothermy and cold resistance in mice. Experientia, 1962, 18 , 28 2-284.

LEVINE, $S$ ALPERT $M$ \& LEWIS, $G$. W Differential maturation of an adrenal response to cold stress in rats manipulated in infancy. Journal of Comparative \& Physiological Psychology, $1958,51,774-777$

LEVINE, S., \& LEWIS, G. W. Critical period for the effects of infantile experience on maturation of stress response. Science, $1959,129,42$.

NAGY, $Z$. M. Tolerance to cold and development of adaptation to cold in mice as a function of age. Physiology \& Behavior, 1966, 1, 327-330.

PINCUS, G., STERNE, G. D., \& ENZMANN, E. The development of temperature regulation in the mouse. Proceedings of the National Academy of Sciences, 1933, 19, 729-733.

SCHAEFFER, T. Early "experience" and its effects on later behavioral processess in rats. II. A critical factor in the early handling phenomenon. Transactions of the New York Acaderny of Sciences, $1963,25,871-889$. 